\title{
Rationing healthcare: Should life-style be used as a criterion?
}

\author{
Sağlık hizmetleri kişisel yaşam biçimine göre sunulmalı mı?
}

\author{
Zümrüt Alpınar, Murat Civaner¹, Yaman Örs² \\ Department of Philosophy, School of Literature, Middle East Technical University, Ankara \\ ${ }^{1}$ Department of Medical Ethics, School of Medicine, Uludag University, Bursa \\ ${ }^{2}$ Department of Medical Ethics (Ret.), School of Medicine, Ankara University, Ankara, Turkey
}

\section{ABSTRACT}

Health is considered as important due to its impacts on individuals' lives. Although individual health level is determined partly by the accessibility of the services and their quality, there are many other factors that may influence an individual's health condition, which are mainly social determinants. Since there are many factors that determine health conditions of the individuals, it would be wrong to hold someone totally responsible for her health condition on the basis of her life-style; such as prudency. Indeed, before deciding about whether the patient was prudent or not; first, we have to look at those determinants of health, and investigate whether there is an effective intervention to avoid those determinants. Furthermore, life-styles of the individuals, which are thought to be the personal choices, are just one of the relatively less effective factors that may influence a person's health and also the autonomy of those choices is controversial. In our paper, we will endeavor to develop an argument showing that since health is one of our primary goods that needs to be protected as one of our basic human rights, and since the health status of individuals are not determined only by their personal choices, we claim that it would be unfair to consider accessing healthcare as something removable or limitable based on conditions other than medical criteria. (Anadolu Kardiyol Derg 2010; 10: 367-71)

Key words: Health care rationing, resource allocation, health policy, life style, medical ethics, bioethics

ÖZET

Sağlığın kişi yaşamında çok önemli bir yere sahip olduğu kabul edilir. Bireysel sağlık kısmen kişinin erişebildiği sağlık hizmetlerinin niteliğine bağlı olsa da, toplumsal belirleyenler gibi pek çok etken sağlık düzeyi üzerinde etkilidir. Sağlık çok çeşitli etkenlerle belirlendiğinden, kişileri sadece yaşam biçimlerini göz önüne alarak, sağlık durumlarından sorumlu tutmak doğru olmaz. Kişinin kendi sağlığını korumak için yeterince çaba gösterip göstermediğini, sağlığa zararlı alışkanlıklardan uzak durup durmadığını değerlendirmeden önce, sağlığın temel belirleyenleri dikkate alınmalıdır. Ayrıca, çoğu zaman kişisel tercihler sonucunda belirlendiği düşünülen yaşam biçimi, hem sağlık üzerinde diğer etkenlerden daha az etkilidir, hem de bu seçimlerin ne kadar özerk seçimler olduğu tartışmalıdır. Bu makalede sağlık hizmetlerine erişim hakkının temel bir insan hakkı olması ve sağlığın kişisel tercihlerin ötesinde çok belirleyenli bir olgu olmasına dayanarak, sadece kişisel yaşam biçimine bakılarak kişilerin sağlık hizmetlerine erişimlerinin kısıtlanamayacağı, bunun için geçerli tek ölçütün tıbbi ölçüt olduğu savunulmaktadır. (Anadolu Kardiyol Derg 2010; 10: 367-71)

Anahtar kelimeler: Sağlık hizmetlerinin dağıtımı, kaynakların dağııımı, sağlık politikaları, yaşam biçimi, tıp etiği, biyoetik

\section{Introduction}

It is oftenly mentioned that one of the main problems in healthcare service providing is the scarcity of resources. Some shortages such as insufficient number of beds and devices may lead to life-threatening conditions for patients or lack of devices for certain tests may increase the cost of these tests. Also, the scarcity of qualified healthcare workers is a major drawback for the diagnosis, treatment and care of the patients. The scarcity of resourc- es can be so striking in cases like transplantation especially, because scarcity of organs may lead to life-threatening conditions (1-4). In addition to that, shortages caused by the scarcity of resources "can lead to inequities in the distribution of ... [healthcare] services, where the economically or socially disadvantaged may be denied opportunities due to their lack of political and social influence or ability to pay" (5). Therefore, with the scarcity of resources in healthcare services in general, many ethically problematic issues are raised (6-9). For instance, due to the scar-

Address for Correspondence/Yazışma Adresi: Dr. Murat Civaner, Uludağ Üniversitesi, Tıp Fakültesi, Halk Sağlığı Anabilim Dalı, 16059, Görükle, Bursa, Turkey

Phone: +90 2242954272 Fax: +90 2244428313 E-mail: mcivaner@gmail.com

This study was presented at IX. World Congress of Bioethics, Crotia, September 3-8, 2008

Accepted/Kabul Tarihi: 24.06.2010

(C) Telif Hakkı 2010 AVES Yayıncılık Ltd. Stti. - Makale metnine www.anakarder.com web sayfasından ulaşılabilir.

(C) Copyright 2010 by AVES Yayıncılik Ltd. - Available on-line at www.anakarder.com doi:10.5152/akd.2010.119 
city of resources, waste prevention should be one of the main concern for rationing healthcare services, while respecting right to healthcare at the same time. Some may claim that the prudency or responsibility of the patient may be considered at this point (1014). It might be argued that prudency or more generally, the lifestyle of the patient should be used as a criterion in order to prevent resource waste or, speaking more generally, to decide who should have the priority to have the required treatment. Then the question is could prudency be used as a criterion in order to decide about a patient? This question leads us to consider whether the individual can be held totally responsible for her health condition or whether there are external factors, such as social status of the individual that may influence an individual's health in a more concrete way. If the existence of external factors can be verified then the claim that prudency could be used as a criterion will obviously fail.

Throughout this paper, we will try to argue against the idea that since there is the scarcity of resources; such as organs or an insufficient number of beds, access to healthcare could be limited on the basis of life-styles of individuals; such as being imprudent. We will endeavor to develop our argument on the basis of the idea that since healthcare is a need and access to healthcare is a right, nobody can be denied access to the related healthcare services. The only reason for an individual to be denied adequate healthcare can be her inability to fulfill the required medical criteria. In addition, the claim that the health level of an individual is determined by some external factors, other than the personal lifestyle, will be used to support our argument. Indeed, we argue that in order to look for whether an individual is prudent or not; first, we should consider the social conditions that she is being exposed to which determine her health status significantly and which are probably beyond her control.

\section{Proposed and applied criteria}

\section{Medical criteria}

In order to discuss whether prudency could be used as a criterion or not, proposed and actually applied criteria for rationing healthcare services should be mentioned first. One of the criteria is the medical one; it is based on scientific knowledge and professional experience, and evaluated and determined by patient's actual health status. These criteria are necessary for the diagnosis/treatment process of patients, including their condition before and after the treatment. For instance, physicians should consider the patient's survival rate after the surgery according to her current health state, medical history and so on. Such criteria are considered case by case and priority for accessing services is determined by the urgency and importance of medical problem. Medical criteria are free from personal features and therefore they are objective decisions.

An important point regarding medical criteria should be stressed here. For medical practitioners, one of the most significant medical criterion is the success rate of the treatment. The success of the surgical intervention seems to include a calculation of cost-benefit. For instance, in transplantation, since there is the scarcity of organs, medical practitioners take into consideration the benefit yielded from the transplantation, such as the number of years to be gained from transplantation (15). However, it would be wrong to assume prejudicially that there are some "risk patients, such as the elderly, whose long term results are significantly worse than those of 'ideal' candidates" (16). In fact, it should also be taken into account that some elderly patients should not be accepted as typical 'risk' patients for the surgery needed for transplantation just because of their ages. Probably, the survival rate of the patient decreases when she has a chronic disease or is elderly. If the elder patient has some diseases related to her age, then she could be designated as a 'risk' patient and she may not be accepted for surgery according to medical criteria. However, the success rate of the surgery can sometimes be high, although the patient is elder. Here, we would like to emphasize that the patients have to be considered individually in the light of medical criteria only.

It might be questioned here a case about two patients, who have the same disease and are both severely ill; however, the only difference between them is that one is the elderly patient while the other one is a younger patient. It might be asked, in such a case to whom the priority should be given. Here, the physician should take into consideration the medical criteria in order not to lead a discrimination among patients. If both patients have the same medical criteria (except for the fact that age is sometimes should be taken into consideration as a medical criterion as it was mentioned in the paragraph above, since there are age related diseases and elderly patient's body may not get over the surgery successfully), then application queue and the waiting period should be considered. However, the point that should be emphasized here is that the priority ought not to be given to the younger patient instead of the older patient just by considering their ages.

\section{Socio-economic considerations}

Although using the word "criteria" may sound a bit striking when it is used together with "socio-economic", we can observe that people may be denied access to services due to their socioeconomic conditions; their inability to pay, for instance. Although not being expressed so clearly, there seems to be socio-economic criteria that are taken into consideration instead of medical criteria. When we think of socio-economic considerations, non-medical criteria seems to be related to patient's ability to afford the treatment, her state or influence in and benefits to the society, the moral value attributed to her by others and her social desirability. In some cases, a patient's ability to pay is taken into consideration in order to benefit from a service; although it might be a decision concerning "a matter of life and death". For example, the patients who are waiting for a marrow transplant and are unable to afford the cost of the tests are not put in the list in the United States because the tests for each found marrow are very expensive (5). Moreover, there may occur some ethical dilemmas, for instance in transplantation cases; if a suitable organ or tissue is found, which patient should have it? It has always been a hard task to overcome such dilemmas, but since medicine is an applied scientific discipline, a decision dependent upon scientific criteria should be made. It is expected that the physician should not take into account a person's social status or economic potentials while making a decision about a patient. Such an attitude would lead to giving priorities to those who seems to be more advantaged in accessing health care services whenever they need it just because they are socially and economically in better condi- 
tions. Usually, application of medical criteria solves the problem. But suppose that two patients have suitable medical criteria. However, they have different social worth: one of the patients is a criminal and the other is a primary school teacher. To whom should priority be given? It may be claimed that priority should be given to the primary school teacher, since she may provide more benefit to the society in the future than the criminal (17). It may also be argued that the criminal is socially less desirable. In this sense, society seems to attribute some moral worth to persons in sometimes ethically doubtful or questionable ways. That would also lead to see those people as if they were socially more worthy than others and they had a priority in using their fundamental right. Such an attitude would lead to a discrimination which is not compatible with professional values (Some may adopt some sort of extreme utilitarian approach concerning human beings in general and see a person basically as a means to further ends. For most of us, however, there is a disturbing aspect to the idea of seeing people almost as mere devices for social improvement. In order not to get out of the topic, we should go on with considering the social determinants affecting a person's health.).

\section{Would it be fair to rationalize the healthcare services according to personal prudence?}

To this point, we have attempted to review the problem created by scarcity of resources and the criteria proposed and applied to determine the priorities. As was mentioned before, we claim that limiting or removing the possibility of accessing healthcare based on conditions other than medical criteria would be unfair, and therefore unacceptable. There are two main premises on which our argument is grounded, namely, the existence of right to healthcare, and the multifactorial nature of health.

\section{Right to healthcare}

Health, providing people with normal functioning, is considered important. In order to emphasize the importance of health, it can be claimed that health conditions might have a great impact on people's life prospects. Moreover, it can also be argued that if people cannot get adequate healthcare when they need it, the possibility of using other rights they have and their potential to fully develop themselves would be diminished. Therefore, it should be accepted as a fact that, as a basic human right, everyone has a right to get adequate healthcare she needs without any regard to her inability to afford the services:

“Everyone has the right to receive ... healthcare as is appropriate to his or her health needs, including preventive care, and activities aimed at health promotion" (18).

This is one of the fundamental human rights (19) and by its nature, it cannot be limited under any circumstances. This is the main reason behind the moral duty to provide healthcare services to criminals or prisoners of war; respect for that fundamental right is the essence for respecting human dignity regardless of the personal features of a specific human being. Rights, either moral or legal ones, may be subject to limitation, suspension or termination under certain conditions; but this case is not applicable for natural rights such as right to health care, as it would be against the very nature of the natural right concept. Defining conditions of limitation for a natural-therefore-unconditional right would render the concept itself meaningless. So, rationing healthcare services according to any criteria other than medical ones is against the right to access to healthcare needed, and therefore taking into consideration the personal choices such as life-style would be unacceptable.

\section{Social determinants of health}

Preventing and promoting our health is sometimes thought to be dependent mainly on ourselves; we can be healthier if we take good care of ourselves by doing regular exercises, and/or by not smoking or drinking too much alcohol. However, it is known that health is not solely determined by the life-style of a person, or the quality of healthcare services that she can access, but there are also many factors that determine the health level of an individual. Besides life-style and genetic features, factors which can be called as social determinants, such as social class, sheltering conditions, nutrition, working conditions, the conditions of the environment in which she lives, education level etc. may be crucial. Michael Marmot states this fact as "poor social factors may produce poor health" (20). If a person lives in a damp flat for a long time, she would be expected to have more frequent respiratory infections, possibly with serious health problems in her later life or if a person did not have clean water for her daily use, then she could possibly have serious health problems due to microbiological causes. For another instance, Mel Bartley suggests that "smoking is in some sense 'caused' by socio-economic disadvantage" (21). He maintains that "socio-economic disadvantage makes it harder to give up smoking and therefore means that smoking-related diseases will be more common in disadvantaged people". He also states that living in a disadvantageous status may also lead to poor health even if one does not smoke, since one has to live in a "damp house", experience "hazardous work," etc. James P. Smith mentions Whitehall studies and asserts that:

"Micro and macro social and economic environments alter human biological functioning. Within the Whitehall study, the principle maintained hypothesis [the social health gradient] appears to be that psychosocial factors, such as workrelated stress and social support networks, have major roles to play in the social gradient in health both directly and indirectly by encouraging poor health behaviors" (22).

The connection between health and wealth has also been pointed out by Daniels et al. (23) who emphasize that social inequalities may lead to inequalities in health: "Some of these [inequalities] occur at the societal level, where income inequality patterns the distribution of social goods, such as public education, thereby affecting patterns the access to life opportunities which are in turn strong determinants of health". Hence, we can arrive at the conclusion that social conditions have an undeniable impact on the health status of people. Here one could ask the question whether it is the person's own choice to live under such conditions, dwelling in that damp flat or using that unclean water? The answer to such questions would be "no". No one would deliberately choose, normally, to endanger their lives with such unhealthy conditions.

It useful to consider our claim by means of a frequently referred example, alcoholism (12, 13, 24-26). Alcohol dependence is accepted as a disease. Alcoholism "is due to a combination of genetic, psychological and social factors-an interaction between 
the person, the substance [alcohol] and the environment. For instance, children of alcoholic parents are more likely to become alcoholics and also it is believed that it passes from "parents to children and from them to the children's children. For a combination of genetic and environmental reasons, children of alcoholics are at a high risk of developing into alcoholics themselves" (27). Furthermore, the brain's structure plays an important role:

"Individual susceptibility to alcoholism may be due to some biochemical imbalance in the system. Recent studies point to possible deficiencies of a chemical in the brain, the neurotransmitter serotonin.... Experiments with serotonin levels and alcohol consumption show that as drinking goes up, the serotonin level drops. Scientists are also finding that alcoholics and nonalcoholics may have differences in the activity of certain enzymes. The lowered activity of these enzymes could affect certain significant functions in the brain and could be a contributing factor that might lead to alcoholism" (27).

Therefore, it can be claimed that there are both genetic and biological factors and also social and environmental factors that would make some people more susceptible to alcoholism. Due to some personal traits, poor mental health, family characteristics, environmental and social factors, people might become alcohol dependent. Psychological factors also play an important role in becoming alcohol dependent. One may start to get alcohol in order to reduce her emotional pain or due to a psychological reason such as depression or stress. No one chooses to have depression, however. In addition, genetic factors play an important role in certain cases of depression. Finally, the living conditions (socially and economically) may lead one to drink alcohol.

As we have argued above, alcohol dependence may have many causes, which are not solely related to a person's own choices. There may be facts, which are beyond one's control. Therefore, it does not seem very reasonable to argue for accepting prudency as a valid criterion. Also, it seems difficult to decide whether an individual was prudent enough or not without knowing what exactly the socio-economic conditions that she were exposed to. Furthermore, it is wrong to make a moral evaluation to decide which patient should have the medical care because of their life-styles, as it is impossible for an external observer/body to assign a value to an individual's life. The alcoholic, regardless of its causes, "should be treated as an ill person" (28). Therefore, we claim that only thing that should be taken into consideration is not the "viciousness" of the alcoholics, the social undesirableness of the patients or the imprudency of them, but only the medical criteria, which are scientific.

\section{Conclusion}

Throughout this paper, we have tried to argue that taking into consideration socio-economic or non-medical criteria, especially the prudency of a person, instead of medical criteria would be unfair. A patient must be considered individually, unrelated to her social worth, her ability to pay or her prudency. Since access to healthcare is one of our basic rights, it cannot be limited by personal features such as prudency, financial status or any other barriers. In addition, we have endeavored to develop our argument by emphasizing the social determinants of health; namely, that a per- son may not be claimed to be totally responsible for her health status. In order to avoid misunderstandings, it should be noted here that we are not claiming that a person cannot be held accountable for her acts. The point we attempt to emphasize is that a person's health condition, might not necessarily be of her own free choice. There may be other external factors; psychological, environmental or social that led her to such a state and for which she cannot be held responsible. Therefore, before considering whether a patient is responsible for her own health condition, for instance, by being prudent; first, we have to take into consideration those determinants of health and have to investigate whether there is an effective intervention to avoid those determinants.

For all of these reasons, we argue that it is ethically doubtful to make judgments about an individual's life-style without seriously taking into consideration all determinants of health. It would be unacceptable to take into consideration non-medical criteria such as personal prudency when making rationing decisions about a patient; only medical criteria should be used.

Conflict of interest: None declared.

\section{References}

1. Erbasan 0, Kemaloğlu C, Bayezid Ö. Heart transplantation. Anadolu Kardiyol Derg 2008; 8: 131-47.

2. Yağdı T, Nalbantgil S, Engin C, Zoghi M, Özbaran M. Donor management in heart transplantation. Anadolu Kardiyol Derg 2004; 4: 339-45.

3. Civaner M, Önal G. Ulusal böbrek bekleme listesi: Tıp etiği açısından bir değerlendirme. In: Erdemir AD, Öncel Ö, Zeytin Z, Türkmen $\mathrm{HÖ}$, Erer S, Erkin $\mathrm{H}$ et al. editors. Proceedings of 1 st International Congress on Medical Ethics and Law; 2007 Oct 17-20; Antalya, Turkey. İstanbul: Nobel Matbaacılık; 2007. p. 525-8.

4. Civaner M, Alpınar Z, Örs Y. Why would opt-out system for organ procurement be more fair? In: 9th World Congress of Bioethics Book of Abstracts; 2008 Sept 3-8; Rijeka, Croatia. Rijeka: University of Zagreb; 2008. p.222.

5. Dewar DM. Allocating organ transplant services: what can be learned from the United States experience? Rev Soc Econ 1998; 56 : 157-74.

6. Civaner M. Kaynakların dağıtımı: Tıp etiği açısından temel kavramlar ve sorunlar. In: Erdemir AD, Atıcı E, Civaner M, Erer S, Öncel Ö, editors. Proceedings of 3rd Symposium of Medical Ethics and Medical Law; 2008 Nov 6; Bursa, Turkey. İstanbul: Nobel Yayın Dağıtım; 2009. p.143-9.

7. Alpınar Z, Sol A. Fairness by inequity in transplantation and general health care. In: Demirhan Erdemir A, Öncel Ö, Zeytin Z, Öztürk Türkmen $\mathrm{H}$, Erer $\mathrm{S}$, Erkin $\mathrm{H}$, et al. editors. Proceedings of $1 \mathrm{st}$ International Congress on Medical Ethics and Law; 2007 Oct 17-20; Antalya, Turkey. Istanbul: Turkey; 2007. p. 731-9.

8. Civaner M. Önemli bir etik sorun alanı olarak yaşamın son dönemi. Toplum ve Hekim 2003;182:148-51.

9. Oğuz NY, Miles SH, Buken N, Civaner M. End-of-life care in Turkey. Camb 0 Healthc Ethics 2003; 12: 279-84.

10. Buyx AM. Personal responsibility for health as a rationing criterion: why we don't like it and why maybe we should. J Med Ethics 2008; 34: 871-4.

11. Denier Y. On personal responsibility and the human right to healthcare. Camb 0 Healthc Ethics 2005;14: 224-34.

12. Glannon W. Responsibility, alcoholism, and liver transplantation. J Med Philos 1998; 23: 31-49.

13. Glannon W. Responsibility and priority in liver transplantation. Camb 0 of Healthc Ethics 2009; 18: 23-35. 
14. Cappelen AW, Norheim OF. Responsibility, fairness and rationing in health care. Health Policy 2006; 76: 312-9.

15. Valapour M. Ethics of organ distribution in lung transplantation. Minn Med 2004; 87: 36-7.

16. Schmidt VH. Selection of recipients for donor organs in transplant medicine. J Med Philos 1998; 23: 50-74.

17. Örs Y. A matter of life and death: pitfalls in the ethics of organ transplantation. Global Bioethics 1995; 8: 1-11.

18. World Health Organization. Regional Office for Europe. A Declaration on the Promotion of Patients' Rights in Europe: European Consultation on the Rights of Patients, Amsterdam, 28-30 March 1994. Geneva : World Health Organization, 1994. (ICP/HLE 121)

19. WHO. Joint Fact Sheet WHO/OHCHR/323. 2007 (cited 2009 Dec 25). Available from: URL: www.who.int/mediacentre/factsheets/fs323_ en.pdf.

20. Marmot M. Social causes of social inequalities in health. In: Anand S, Peter F, Sen A, editors. Public Health, Ethics, and Equity. New York: Oxford University Press; 2004. p. 37-61.
21. Bartley M. Health inequality: an introduction to theories, concepts and methods. Cambridge: Polity Press; 2004.

22. Smith JP. Healthy bodies and thick wallets: the dual relation between health and economic status. J Econ Perspect 1999; 13: 144-66.

23. Daniels N, Kennedy B, Kawachi I. Health and inequality, or, why justice is good for our health. In: Anand S, Peter F, Sen A, editors. Public Health, Ethics and Equity. New York: Oxford University Press; 2004. p. 63-91.

24. Ho D. When good organs go to bad people. Bioethics 2008; 22: 77-83.

25. Brudney D. Are alcoholics less deserving of liver transplants? Hastings Cent Rep 2007; 37: 41-7.

26. Wittenberg E, Goldie SJ, Fischhoff B, Graham JD. Rationing decisions and individual responsibility for illness: are all lives equal? Med Decis Making 2003; 23: 194-211.

27. Berger G. Alcoholism and the family. New York: Franklin Watts; 1993.

28. Jones KL, Shainberg LW, Byer CO. Drugs, alcohol and tobacco. San Francisco: Canfield Press; 1990. 